$9-1-2000$

\title{
Characteristics of Nursing Doctoral Programs in The United States
}

\author{
Melanie McEwen \\ Baylor University \\ Gregory A. Bechtel \\ Baylor University
}

Follow this and additional works at: https://engagedscholarship.csuohio.edu/nurs_facpub

Part of the Nursing Commons

How does access to this work benefit you? Let us know!

\section{Publisher's Statement}

NOTICE: this is the author's version of a work that was accepted for publication in Journal of Professional Nursing. Changes resulting from the publishing process, such as peer review, editing, corrections, structural formatting, and other quality control mechanisms may not be reflected in this document. Changes may have been made to this work since it was submitted for publication. A definitive version was subsequently published in Journal of Professional Nursing, 16, 5, 2000 DOI\#10.1053/jpnu.2000.9458

\section{Recommended Citation}

McEwen, Melanie and Bechtel, Gregory A., "Characteristics of Nursing Doctoral Programs in The United States" (2000). Nursing Faculty Publications. 35.

https://engagedscholarship.csuohio.edu/nurs_facpub/35

This Article is brought to you for free and open access by the School of Nursing at EngagedScholarship@CSU. It has been accepted for inclusion in Nursing Faculty Publications by an authorized administrator of EngagedScholarship@CSU. For more information, please contact library.es@csuohio.edu. 


\title{
Characteristics of N ursing D octoral Programs in the United States
}

\author{
Melanie McEwen, RN, PhD, and Gregory A. Bechtel, MPH, PhD
}

$\mathbf{N}$

URSING DOCTORATES are a relatively new phenomena in the health sciences with the greatest growth occurring in the past 2 decades of the past century. In 1960, there were only 4 doctoral programs in nursing but the number increased to 30 by 1984 and to 48 in 1989 (Rickelman \& Brown, 1989). Currently, there are 75 nursing doctoral programs or collaborative groups offering the research $(P h D)$, education (EdD), or clinical doctorate (D N S/ D N Sc and ND) located in 81 colleges or universities in the U nited States. This expansive growth of doctoral education, coupled with the rapidly increasing knowledge base in the discipline of nursing, suggests the need for a systematic examination of doctoral education programs. With the demand for doctorally prepared nurses expected to increase dramatically (H odges, Satkowski, \& Ganchorre, 1998), new pro- grams should offer unique and innovative programs of study and not simply duplicate existing nursing doctoral education programs.

Although growth in the number of doctoral nursing programs must continue to meet the increasing demands of an educated and health conscious society such growth should occur in an orderly progression that balances the educational needs of the profession with available resources. Curricula trends and outcomes should be reviewed, especially regarding the different types of degrees and programs, because the roles of doctorally prepared faculty have changed with the advent of increased research, teaching, and service opportunities.

Ultimately, the rapid proliferation of programs, coupled with an absence of degree-specific accreditation, raises serious pedagogical questions. These questions and issues have been previously addressed (Blancett, 1989; Grace, 1989), but recent information is necessary to accurately reflect the essence of doctoral programs and assist with the allocation of scarce financial and human resources. U Itimately, the knowledge gained from such information could provide an effective framework for facilitating the development of new programs of study. This information is also a necessity for the student and future nurse scientist. Jones and Lutz (1999) addressed the importance of finding a "good fit" between the student and a doctoral program to enhance satiffaction, avoid role conflict and disillusionment, and promote satisfaction with research and other learning opportunities. Thus, establishing both common and distinguishing characteristics of doctoral programs may lead to a greater understanding of the roles and obligations of educators who will prepare nurses to assume greater responsibilities and leadership in the future.

This project was undertaken to assess the status of doctoral programs in the U nited States. The purpose was to collect information related to curricula, admission and progression criteria, focus of study, and distance education offerings, and to compare programs based on several variables. This study will be beneficial for: (1) faculty who are planning new 
doctoral programs in nursing; (2) faculty who currently teach at doctoral programs and might be interested in program revision; and (3) potential students who would like information on options for obtaining a doctorate in nursing.

\section{Review of the Literature}

Although Starck, Duffy, \& Vogler (1993) and Christman (1998) suggested a need for doctoral faculty to be clinically proficient within the rapidly changing American health care system, the primary responsibility of graduates after the attainment of the doctorate in nursing remains nursing education. De spite this, there is a conspicuous absence of the teaching role of doctorally prepared nurses in the literature. Indeed, a research focus remains the primary component of most nursing doctorate programs in the United States.

D owns (1989) conducted the first overall review of doctoral programs in the United States comparing $\mathrm{PhD}$ and DNS programs with regard to curricula, research, and clinical requirements. Although differences in clinical and research course allocation was found between clinical and research doctorates, the wide variety of programs yiel ded too much conflicting data to make any concrete or definitive statement.

In another study conducted in the late 1980s, Ziemer et al. (1991) reported on curricular elements common to doctoral programs at that time. They found that the components of research designs, methods, and techniques of analysis and theory construction were covered by all of the programs that participated in their study. Theory construction was also a component of the curriculum in almost all of the programs. Student research opportunities were available in only two thirds of the programs whereas social, ethical, and political issues were components in slightly more than half. Data management, tools/ technology, and existing substantive nursing knowledge comprised 45 per cent and 41 per cent of doctoral programs, respectively.

In another article reporting on a survey of 39 doctoral programs in nursing, Ziemer et al. (1992) described the most common curricular requirements. The courses and the percentage of doctoral programs with the stated requirement were: nursing theory (100 per cent), research (100 per cent), quantitative analysis (85 per cent), philosophy (74 per cent), and issues in nursing (67 per cent). The investigators listed the mean number of credit hours for courses as theory (6 credits), research (7.9 credits), quantitative analysis
(7.4 credits), philosophy (4.7 credits), issues (4.6 credits), qualitative methods (3.5 credits), computer skills development (2.8 credits), research with faculty (10.0 credits), clinical (11.0 credits), role development (9.4 credits), statistics (6.4 credits), cognates/electives (10.6 credits), and dissertation/dissertation seminar (17.7 credits). Thirty-five of the 39 programs (89.7 per cent) reported sometype of qualifying/comprehensive examination and 5 of the 39 programs (12 per cent) had a foreign language competency requirement.

To address concerns over the proliferation of doctoral programs in the early 1990s, the American Association of Colleges of N ursing (AACN) (1993) reported that essential doctoral program components included faculty quality, student characteristics, and expectations of students and faculty. Common curricula essentials for quality doctoral programs were: (1) history, philosophy, and nursing knowledge; (2) substantive nursing knowledge; (3) theory construction; (4) social, ethical, and political issues related to nursing; (5) research designs, methods, and analysis; (6) data management, tools, and technology; and (7) research opportunities.

A number of issues have been raised questioning the focus of doctoral programs. M eleis (1992) expressed concern that doctoral programs focused too much on research, theory, and statistics rather than substantive areas of knowledge unique to nursing. Christman (1998) concurred, stating that many PhD programs are weak in clinical methods and that research methodology is the "centerpiece" of the curriculum.

Ketefian (1993) argued that the majority of doctoral curricula concentrate on process courses (research methods, statistics, theory development, philosophy of science, and so forth) rather than nursing content. Furthermore, it is noted that students have been guided in the selection of cognate courses from other disciplines that, in effect, have become the substantive component of their program of study. This supports the ideas of Starck, D uffy, \& Vogler (1993) who advocated change to emphasize practice-focused doctoral curricula to produce senior clinicians and expert practitioners.

Finally, Gosnell and Biordi (1999) reported on a survey to compare resource distribution of nursing programs based on the Carnegie classification of the university. They found that Research I institutions had more tenured faculty and Research II institutions had the fewest faculty and most students. The Research I institutions emphasized development, computers, and statistical support more than other programs and 
TABLE 1. Survey Respondents by Geographic Location

\begin{tabular}{llcr}
\hline \multicolumn{1}{c}{ Location of Nursing Program } & \multicolumn{1}{c}{ States } & $\begin{array}{c}\text { Number of } \\
\text { Programs in Sample }\end{array}$ & $\begin{array}{c}\text { Total Number of } \\
\text { Programs in Area }\end{array}$ \\
\hline North Eastern United States & Connecticut, Massachusetts, New Jersey, New York, & 11 & 18 \\
Mid-Atlantic/South East United States & Pennsylvania, Rhode Island & 10 & 16 \\
North Central United States & District of Columbia, Florida, Georgia, Maryland, Virginia & 10 & 17 \\
South Central United States & Illinois, lowa, Michigan, Minnesota, Missouri, Ohio & 10 & 16 \\
Western United States & Arkansas, Kansas, Mississippi, Tennessee, Texas & 7 & 8 \\
\hline
\end{tabular}

subsequently spent more resources on students than did other programs.

\section{Instrument}

A researcher-developed questionnaire was used to ascertain (1) demographic information on the school, (2) characteristics of students enrolled in the doctoral program, (3) admission requirements, (4) distance education offerings, (5) curriculum content, and (6) qualifying examination criteria. 0 pen-ended questions allowed the participants to describe program evaluation methods and the unique characteristics of their respective institutions.

\section{Sample and Method}

The sample consisted of all of the doctoral programs identified by AACN (1998). In the summer of 1999, there were 70 nursing programs located in 78 schools of nursing. Several states had more than 1 program (e.g., Texas Tech and the U niversity of Texas at San Antonio; University of M assachusetts at Boston, Amherst, and Lowell; Medical University of South C arolina and U niversity of South C arolina) that are joint or collaborative programs granting a single degree.

The dean of each of the 78 listed schools was sent a survey packet with a cover letter explaining the purpose of the survey, a survey form, and a selfaddressed stamped envelope for return of the questionnaire. After 6 weeks, a follow-up contact was made via e-mail. Of the 78 doctoral nursing programs in the United States, 48 returned the survey form for a response rate of 62 per cent. The overwhelming majority $(n=44)$ offered the PhD, 4 offered a D NS/D N Sc/D SN, and 2 offered an ND. O ne program offered the $P h D$ and a D N Sc, 1 program offered a D N Sc and ND, and 1 program offered $a P h D$ and ND.

Schools were coded by geographic locality and by the Carnegie Research Classification (H igher Educa- tion D irectory, 1998). The results were entered into a data file using SPSS-PC (SPSS, Inc., 233 S. Wacker D r., Chicago, IL 60606). A confidence level of 0.05 was predetermined.

\section{Findings}

\section{Demographic Characteristics}

The reported data was analyzed by researcherdefined geographic areas and are presented in Table 1. Thirty-seven states and the District of Columbia currently have nursing doctoral programs. States without doctoral programs in nursing include Alaska, Delaware, Idaho, Maine, M ontana, N evada, N ew Hampshire, N orth Dakota, Oklahoma, South Dakota, Vermont, West Virginia, and Wyoming. The majority of the responding nursing programs were located east of the M ississippi river.

Consistent with the literature, the sample revealed the comparative youth of doctoral programs in the U nited States. M ore established programs tended to have a greater number of students, enrolled more full-time students, and graduated more students each year (Table 2). The average length of time of all doctoral nursing programs that have been in existence is 12.8 years, with the oldest program in the sample admitting their first group of students in 1934 and the newest program admitting their initial class in the fall of 2000. The length of time programs have been in operation were characterized as less than 10 years ( $n=18,38$ per cent), 10 to 19 years ( $n=19,40$ per cent), and greater than 20 years ( $n=11,22$ per cent).

\section{Characteristics of Doctoral Students}

TABLE 2. Student Variables by Age of Program

\begin{tabular}{lrrr}
\hline \multicolumn{1}{c}{ Student Variables } & $\begin{array}{c}\text { Programs } \\
\text { <10 Years }\end{array}$ & $\begin{array}{c}\text { Programs } \\
11-19 \text { Years }\end{array}$ & $\begin{array}{c}\text { Programs } \\
20+\text { Years }\end{array}$ \\
\hline Number of students per year & 5.75 & 6.94 & 10.50 \\
Number of students enrolled & 19.69 & 40.47 & 63.67 \\
Number of full-time students & 7.69 & 16.87 & 38.36 \\
Number of graduates per year & 2.50 & 6.67 & 6.72 \\
Total number of graduates & 2.47 & 64.12 & 126.11 \\
\hline
\end{tabular}


TABLE 3. Information on Doctoral Students

\begin{tabular}{lccc}
\hline \multicolumn{1}{c}{ Student Variable } & $\begin{array}{c}\text { Range Across } \\
\text { Programs }\end{array}$ & Median & Mean (SD) \\
\hline $\begin{array}{l}\text { Students admitted per year } \\
\text { Total number of students }\end{array}$ & $0-20^{*}$ & 7 & $7.46(3.2)$ \\
$\quad$ enrolled & $0-93^{*}$ & 35 & $39.27(24.0)$ \\
$\begin{array}{l}\text { Number of full-time students } \\
\text { Number of part-time stu- }\end{array}$ & $0-90^{*}$ & 12.5 & $19.0(21.98)$ \\
$\quad$ dents & $0-71^{*}$ & 18 & $19.24(14.6)$ \\
$\begin{array}{l}\text { Number of graduates per } \\
\quad \text { year }\end{array}$ & $0-23^{*}$ & 5 & $6.60(5.4)$ \\
$\begin{array}{l}\text { Total number of graduates } \\
\text { Estimated age of doctoral } \\
\text { students }\end{array}$ & $0-470^{*}$ & 28 & $55.17(94.0)$ \\
\hline
\end{tabular}

Abbreviation: SD, standard deviation.

*Does not include ND students.

D octoral student characteristics from the sample are presented in Table 3. The range of responses is quite variable leading to the large SD. For example, the total number of graduates from the programs range from none (a new program) to 470 (University of Texas at Austin). M ost schools have relatively small numbers of students with slightly more students enrolling than graduating each year. Part-time students tend to outnumber full-time students, although some institutions only allow full-time study.

\section{Admission Requirements}

Admission requirements were remarkably consistent across programs. Table 4 shows that two thirds of the programs require a BSN and a MSN, current licensure as a registered nurse, letters of recommendation, proof of ability to perform scholarly work, and an interview. M ean graduate record examination (GRE) scores on verbal/quantitative ranged from 900 to 1,250 with a mean of 1,000 , or 1,350 to 1,800 with a mean of 1,500 on the combined GRE. The average minimum GPA was 3.2 (SD $=0.23$ ). Additional admission criteria mentioned by at least 1 respondent

TABLE 4. Admissions Requirements

\begin{tabular}{lc}
\hline \multicolumn{1}{c}{ Requirement for Admission } & $\begin{array}{r}\text { Percentage } \\
\text { Requiring } \\
\text { Admission }\end{array}$ \\
\hline Degree from accredited nursing program & 89.4 \\
Master's degree in nursing & 66.0 \\
Accept students directly from BSN program & 51.1 \\
Nonnurses & 8.5 \\
GRE & 80.4 \\
Ability to perform scholarly work & 83.0 \\
Current nursing license & 80.9 \\
Interview & 72.3 \\
Letters of recommendation & 89.4 \\
Goal/purpose statement & 55.5 \\
\hline
\end{tabular}

included: (1) commitment to take at least 2 courses per semester, (2) TOFEL for international students, (3) a prerequisite statistics course, (4) evidence of professional activities, (5) English competency (inhouse assessment), and (6) resume/vitae.

\section{Distance Education Options}

O ffering courses via videoconferencing is the most prevalent form of distance education with 27 per cent of all programs offering at least 1 course through this route. $\mathrm{N}$ ineteen per cent offered at least 1 course via the Internet, 2 programs offer courses by videotape, and 1 program offers courses via satellite. Several programs reported that a number of master's level courses are offered via distance education and students may take these as electives. Four respondents reported that some cognate courses were available through distance education.

\section{Curriculum}

Table 5 identifies the doctoral nursing courses and the respective credit hours. The average number of research credit hours was 16.7 with 8.2 hours in nursing science/philosophy and nursing theory. The programs require an average of 9 credit hours of cognates. The most commonly reported areas for study outside of the discipline of nursing were physiology, psychology, sociology, ethics, and anthropology (each mentioned by morethan 5 respondents); philosophy, and public health/epidemiology (4 respondents), and statistics (3 respondents).

\section{Dissertation}

$D$ issertation hours were surprisingly variable. Seven respondents did not provide a total number of credit hours for dissertation, but for the remaining 41 programs the hours allocated for dissertation ranged between 1 and 30. The mean number of credit hours was 13.3 (SD = 7.31) and the most common re sponse was 12 credit hours, which was required by 16 programs (39 per cent). Eleven programs (27 per cent) reported requiring less than 12 hours; 6 (15 per cent) required 13 to 19 hours, and 8 (20 per cent) required $20+$ hours of dissertation credit hours.

\section{Other Requirements}

Two additional program requirements were noted. Two of the programs had a language requirement and 
TABLE 5. Doctoral Program Courses and Credit Hours

\begin{tabular}{|c|c|c|c|}
\hline Course Content & $\begin{array}{l}\text { Percentage of } \\
\text { All Programs } \\
\text { Requiring } \\
2+\text { Hours }\end{array}$ & $\begin{array}{l}\text { Median } \\
\text { Number of } \\
\text { Credit Hours }\end{array}$ & $\begin{array}{l}\text { Mean Number } \\
\text { of Credit } \\
\text { Hours (SD) }\end{array}$ \\
\hline $\begin{array}{l}\text { Nursing science/phi- } \\
\text { losophy of nursing }\end{array}$ & 89.4 & 3 & $2.96(1.46)$ \\
\hline $\begin{array}{l}\text { Theory construction/ } \\
\text { theory development }\end{array}$ & 79.7 & 3 & $2.57(1.58)$ \\
\hline $\begin{array}{l}\text { Theory analysis/theory } \\
\text { evaluation }\end{array}$ & 57.4 & 3 & $1.85(2.01)$ \\
\hline $\begin{array}{l}\text { Advanced nursing } \\
\text { research }\end{array}$ & 51.0 & 2 & 2.00 (1.70) \\
\hline Research methodology & 68.0 & 3 & $2.64(2.1)$ \\
\hline $\begin{array}{l}\text { Qualitative research } \\
\text { design }\end{array}$ & 85.1 & 3 & $3.00(1.74)$ \\
\hline $\begin{array}{l}\text { Quantitative research } \\
\text { design }\end{array}$ & 85.1 & 3 & $2.83(1.40)$ \\
\hline $\begin{array}{l}\text { Statistics/advanced } \\
\text { statistics/multivariate } \\
\text { statistics }\end{array}$ & 93.6 & 6 & $5.28(2.89)$ \\
\hline $\begin{array}{l}\text { Instrumentation and } \\
\text { measurement }\end{array}$ & 51.1 & 3 & $1.95(2.06)$ \\
\hline $\begin{array}{l}\text { Research practicum } \\
\text { Clinical practice }\end{array}$ & 62.7 & 1 & $2.18(2.53)$ \\
\hline (excluding research) & 11.6 & 0 & $0.81(2.67)$ \\
\hline $\begin{array}{l}\text { Specialization content } \\
\text { (area of study) }\end{array}$ & 55.3 & 3 & $4.68(5.23)$ \\
\hline $\begin{array}{l}\text { Health care delivery } \\
\text { systems }\end{array}$ & 14.9 & 0 & $0.48(1.03)$ \\
\hline $\begin{array}{l}\text { Health policy (social, } \\
\text { ethical, and political } \\
\text { issues) }\end{array}$ & 46.8 & 1 & $1.48(1.56)$ \\
\hline $\begin{array}{l}\text { Information systems/ } \\
\text { informatics }\end{array}$ & 14.9 & 0 & $0.41(1.02)$ \\
\hline $\begin{array}{l}\text { Grantsmanship/grant } \\
\text { writing }\end{array}$ & 36.1 & 0 & $1.08(1.49)$ \\
\hline $\begin{array}{l}\text { Health promotion/ } \\
\text { health behaviors }\end{array}$ & 17.0 & 0 & $0.68(1.77)$ \\
\hline $\begin{array}{l}\text { Administration/man- } \\
\text { agement }\end{array}$ & 8.5 & 0 & $0.43(1.50)$ \\
\hline $\begin{array}{l}\text { Nursing education/cur- } \\
\text { riculum and instruc- } \\
\text { tion }\end{array}$ & 14.9 & 0 & $0.77(1.97)$ \\
\hline Faculty role/academia & 17.1 & 0 & $0.60(1.11)$ \\
\hline Cognates & 91.5 & 9 & $8.96(4.67)$ \\
\hline
\end{tabular}

Abbreviation: SD, standard deviation.

45 (93.75 per cent) had a comprehensive or qualifying examination requirement.

\section{Program Comparisons}

Four factors were examined to analyze differences among programs: Carnegie Classification, length of time the program has been in operation, location of the program, and degree awarded. Analysis of variance (AN O VA) was performed to detect differences pertaining to student variables, admissions criteria, and curricula. Tukey post hoc testing was used to detect significant differences.

\section{Comparisons by Carnegie Classification}

Of the 48 programs that responded to the survey, 18 (38 per cent) were Research I institutions, 15 (31 per cent) were in health science centers/medical centers; 4 (8 per cent) were in Research II institutions; and 11 ( 23 per cent) were in D octoral I or D octoral II institutions. No differences were found in curricula, student variables, or admission requirements. Significant differences were found in distant education offerings because programs located within medical centers were more likely to use the Internet in the delivery of courses than either Doctoral I or II institutions ( $P=.018)$, Research II institutions $(P=.004)$, and Research I institutions ( $P=.030)$. Programs in medical centers were also significantly more likely to use videoconferencing than Research I institutions ( $\mathrm{P}=.012$ ) or $\mathrm{D}$ octoral I or II institutions $(\mathrm{P}=.003)$.

\section{Comparison by Length of Time Program is in Existence}

For analysis, the programs were sorted into 3 groups by the date students were first admitted. N ot surprisingly, older programs had significantly more students, more graduates, and more full-time students than did newer programs. Themean number of credit hours for health policy was the only significant curriculum difference based on the age of the program. D octoral nursing programs that were more than 20 years old had an average of 0.21 hours (SD $=0.50$ ) of health policy credits compared with programs that are less than 10 years old $(1.88, S D=1.65)$ and those 10 to 18 years $(1.94, \mathrm{SD}=1.51)$. There were no other significant differences based on the age of the program, differences in distance education options, or admissions criteria.

\section{Comparison by Degree Awarded}

There were a few significant differences based on the degree awarded. D N S, D SN, and D N Sc programs were more likely to require a license to practice in the state where the program was located $(P=.002)$ and more likely to require an interview $(P=.000)$ than PhD programs.

Consistent with observations made in the literature, there were only 3 significant differences between PhD and DNS, DSN, DN Sc and programs in curricula. 
First, the research practicum was significantly $(P=.000)$ more common in $\mathrm{PhD}$ programs. DNS, D SN, or D N Sc programs required an average of 0.25 hours of research practicum compared with 2.4 hours for PhD programs. Second, total research hours were also significantly different $(P=.009)$ because PhD programs required 17.3 hours of research and DNS, DSN , or D N Sc programs required an average of 10 hours. Third, nonresearch clinical course hours were significantly different $(P=.000)$ with D N S, D SN , or D N Sc programs requiring an average of 5.25 course hours of clinical compared with 0.40 hours of clinical for PhD programs.

\section{Comparison by Location}

There were 2 significant differences noted between programs based on location. First, programs in the west enroll significantly more students per year $(P=.04)$ than programs in the south central part of the country. Second, doctoral nursing programs in the northeast United States require an average of 3.36 hours of advanced statistics and programs located in the north central portion of the U nited States require 6.8 hours of statistics $(P=.01)$.

\section{Other Findings}

Currently, 75 individual schools or collaborative groups offer doctoral degrees in nursing. These programs are located in 81 different colleges or universities. Of these, 66 programs ( 88 per cent) offer the PhD , 9 (12 per cent) offer the D N S, D SN, or D N Sc, 1 (1 per cent) offers the $E d D$, and 3 (4 per cent) offer the ND (percentages are greater than 100 because 1 program offers both a PhD and a D N Sc; 2 programs offer $\mathrm{P} P \mathrm{Ph}$ and an ND, and 1 program offers a D N S and an ND).

Table 6 provides a comprehensive list of the doctoral programs in nursing and includes the location of the program, website address of the parent institution, type of degree awarded, year the program began, and specialty area or focus area for research where known.

\section{Discussion}

This national survey suggests that doctoral programs in nursing are quite similar with regard to admission criteria, curricula, and the use of distance education, which supports the findings of Hudacek and Carpenter (1998) who found that students per- ceived similarities among program types. Very few differences were noted based on a number of criteria including geographic location, degree granted, Carnegie classification, or age of the program. Although similarities in programs may be valuable in assuring consistency between programs and standardization within doctoral nursing education, such similarities may also inhibit innovative thought processes and curtail the growth of new opportunities in research and teaching.

C riteria for program admissions tend to be consistent. G enerally, programs mandate a degree from an accredited nursing program and a master's degree in nursing. A GRE is usually necessary, with either a score of 1,000 on the combined verbal and quantitative or 1,500 on verbal/quantitative/analytic. A grade point average (GPA) of 3.2, an interview, evidence of an ability to perform scholarly work, a current nursing license, and letters of recommendation were also typically required.

Consistent with previous reports in the literature, curricula are fairly standard. Expected differences were noted based on degree granted, with D N S, D SN , and DN Sc programs much more likely to have clinical components and less likely to have a research practicum than PhD programs. O therwise, differences were notably minor. Based on survey findings, a typical program might include: nursing science/philosophy (3 hours), theory construction/analysis (4 hours), advanced research/methods (5 hours), qualitative re search design (3 hours), quantitative research design ( 3 hours), statistics ( 6 hours), instrumentation and measurement (3 hours), research practicum (2 hours), specialization content (5 hours), health policy and health systems (1 hour), cognates ( 9 hours), and dissertation (12 hours).

An interesting and somewhat unexpected finding occurred when reviewing the data by type of degree because fairly dramatic changes have occurred with regard to the types of degrees awarded. According to Rickelman and Brown (1989), in the late 1980s, 27 per cent of the doctoral programs were D N S, D SN, or D N Sc programs. That percentage is now 12 per cent. $T$ his reduction is caused primarily by 2 factors. $O f$ the 25 programs that began in the 1990s, only 3 (Yale, Columbia, and the University of Texas-H ouston) award the clinical degree. Additionally, during that time several programs moved from granting a D N S, D SN , or D N Sc degree to granting a PhD (University of Alabama-Birmingham, Indiana University, and UCLA). Additionally, 2 other schools that offered both options (University of Pennsylvania and U niver- 
TABLE 6. Doctoral Programs in the United States

\begin{tabular}{|c|c|c|c|}
\hline Location of Program and Website & Degrees Offered & Year Established & Areas of Research Focus (Where Available) \\
\hline $\begin{array}{l}\text { University of Alabama-Birming ham } \\
\text { www.uab.edu }\end{array}$ & $\mathrm{PhD}$ & 1999 & $\begin{array}{l}\text { Health status and function of individuals, fami- } \\
\text { lies, and communities }\end{array}$ \\
\hline $\begin{array}{l}\text { University of Arizona (Tucson) } \\
\text { www.arizona.edu }\end{array}$ & $\mathrm{PhD}$ & 1976 & $\begin{array}{l}\text { Community-based interventions; health sys- } \\
\text { tems; chronic and disabling conditions }\end{array}$ \\
\hline $\begin{array}{l}\text { University of Arkansas for Medical Sciences } \\
\text { (Little Rock) }\end{array}$ & $\mathrm{PhD}$ & 1997 & Research \\
\hline \multicolumn{4}{|l|}{ www.uams.edu } \\
\hline $\begin{array}{l}\text { University of California-Los Angeles } \\
\text { www.ucla.edu }\end{array}$ & $\mathrm{PhD}$ & 1986 & $\begin{array}{l}\text { Clinical nursing research-Biobehavioral studies } \\
\text { that relate to health promotion and disease } \\
\text { prevention; health systems research }\end{array}$ \\
\hline $\begin{array}{l}\text { University of California-San Francisco } \\
\text { www.ucsf.edu }\end{array}$ & $\mathrm{PhD}$ & 1964 & Based on faculty research interests \\
\hline $\begin{array}{l}\text { University of San Diego } \\
\text { www.acusd.edu }\end{array}$ & $\mathrm{PhD}$ & 1985 & $\begin{array}{l}\text { Social, political, and ethical issues in global } \\
\text { health care }\end{array}$ \\
\hline $\begin{array}{l}\text { University of Colorado Health Sciences Center } \\
\text { (Denver) } \\
\text { www.uchsc.edu }\end{array}$ & $\mathrm{PhD}, \mathrm{ND}$ & 1978 & $\begin{array}{l}\text { Human experience of health/illness/healing; } \\
\text { environmental context of health and illness; } \\
\text { human/technology interface; cost-effective/ } \\
\text { quality outcomes }\end{array}$ \\
\hline $\begin{array}{l}\text { University of Connecticut (Storrs) } \\
\text { www.uconn.edu }\end{array}$ & $\mathrm{PhD}$ & 1994 & Nursing research, philosophy, and theory \\
\hline $\begin{array}{l}\text { Yale University (New Haven) } \\
\text { www.yale.edu }\end{array}$ & DNSc & 1994 & $\begin{array}{l}\text { Human responses to chronic illness across the } \\
\text { life span; family and social factors in primary } \\
\text { care; health services delivery and policy }\end{array}$ \\
\hline $\begin{array}{l}\text { Catholic University of America (District of } \\
\text { Columbia) }\end{array}$ & DNSc & 1967 & $\begin{array}{l}\text { Health care systems; patient outcomes; clinical } \\
\text { problems }\end{array}$ \\
\hline \multicolumn{4}{|l|}{ www.cua.edu } \\
\hline $\begin{array}{l}\text { Barry University (Miami Shores, FL) } \\
\text { www.barry.edu }\end{array}$ & $\mathrm{PhD}$ & 1996 & Executive role; professorial role; research role \\
\hline $\begin{array}{l}\text { University of Florida (Gainesville, FL) } \\
\text { www.ufl.edu }\end{array}$ & $\mathrm{PhD}$ & 1984 & $\begin{array}{l}\text { Women's health; aging and health; family } \\
\text { models }\end{array}$ \\
\hline $\begin{array}{l}\text { University of Miami } \\
\text { www.miami.edu }\end{array}$ & $\mathrm{PhD}$ & 1985 & $\begin{array}{l}\text { Qualitative and quantitative clinical research } \\
\text { within a transcultural nursing perspective }\end{array}$ \\
\hline $\begin{array}{l}\text { University of South Florida (Tampa) } \\
\text { www.usf.edu }\end{array}$ & $\mathrm{PhD}$ & 1997 & $\begin{array}{l}\text { Quality of life/end of life; children/families/com- } \\
\text { munities; health services research/policy }\end{array}$ \\
\hline $\begin{array}{l}\text { Emory University (Atlanta) } \\
\text { www.emory.edu }\end{array}$ & $\mathrm{PhD}$ & 1999 & $\begin{array}{l}\text { Integration of nursing science and ethics; } \\
\text { health policy and health outcomes research }\end{array}$ \\
\hline $\begin{array}{l}\text { Georgia State University (Atlanta) } \\
\text { www.gsu.edu }\end{array}$ & $\mathrm{PhD}$ & 1986 & $\begin{array}{l}\text { Family nursing; community nursing and } \\
\text { nursing education }\end{array}$ \\
\hline $\begin{array}{l}\text { Medical College of Georgia (Augusta) } \\
\text { www.mcg.edu }\end{array}$ & $\mathrm{PhD}$ & 1987 & Health care across the life span \\
\hline $\begin{array}{l}\text { University of Hawaii at Manoa } \\
\text { www.hawaii.edu }\end{array}$ & $\mathrm{PhD}$ & 1998 & $\begin{array}{l}\text { Culturally appropriate clinical scholarship; fac- } \\
\text { ulty preparation for nursing programs with } \\
\text { culturally diverse student populations }\end{array}$ \\
\hline $\begin{array}{l}\text { Loyola University of Chicago } \\
\text { www.luc.edu }\end{array}$ & $\mathrm{PhD}$ & 1989 & $\begin{array}{l}\text { Contribute to the body of nursing knowledge in } \\
\text { order to improve the health of society }\end{array}$ \\
\hline $\begin{array}{l}\text { Rush University (Chicago) } \\
\text { www.rush.edu }\end{array}$ & DNSc,ND & 1975 & \\
\hline $\begin{array}{l}\text { University of Illinois-Chicago } \\
\text { www.uic.edu }\end{array}$ & $\mathrm{PhD}$ & 1975 & \\
\hline $\begin{array}{l}\text { Indiana University (Indianapolis) } \\
\text { www.iupui.edu }\end{array}$ & $\mathrm{PhD}$ & 1978 & $\begin{array}{l}\text { Acute and chronic health problems; environ- } \\
\text { ments for health; family health adaptation; } \\
\text { health promotion }\end{array}$ \\
\hline $\begin{array}{l}\text { University of lowa (lowa City) } \\
\text { www.uiowa.edu }\end{array}$ & $\mathrm{PhD}$ & 1988 & $\begin{array}{l}\text { Nursing administration; gerontology nursing; } \\
\text { family nursing (in development) }\end{array}$ \\
\hline $\begin{array}{l}\text { University of Kansas (Kansas City) } \\
\text { www.kumc.edu }\end{array}$ & $\mathrm{PhD}$ & 1983 & $\begin{array}{l}\text { Health behaviors; nursing systems; acute and } \\
\text { chronic illness }\end{array}$ \\
\hline $\begin{array}{l}\text { University of Kentucky (Lexington) } \\
\text { www.uky.edu }\end{array}$ & $\mathrm{PhD}$ & 1986 & $\begin{array}{l}\text { Developing and testing midrange theories; } \\
\text { clinical research }\end{array}$ \\
\hline
\end{tabular}

(New Orleans)

www.Isumc.edu 
TABLE 6. (Continued)

\begin{tabular}{|c|c|c|c|}
\hline Location of Program and Website & Degrees Offered & Year Established & Areas of Research Focus (Where Available) \\
\hline $\begin{array}{l}\text { Johns Hopkins University (Baltimore) } \\
\text { www.jhu.edu }\end{array}$ & $\mathrm{PhD}$ & 1995 & $\begin{array}{l}\text { Molecular genetics; physiology and exercise } \\
\text { physiology; violence; oncology; hyperten- } \\
\text { sion; pain }\end{array}$ \\
\hline $\begin{array}{l}\text { University of Maryland (Baltimore) } \\
\text { www.umd.edu }\end{array}$ & $\mathrm{PhD}$ & 1979 & \\
\hline $\begin{array}{l}\text { Boston College } \\
w w w . b c . e d u\end{array}$ & $\mathrm{PhD}$ & 1988 & $\begin{array}{l}\text { Human responses; clinical judgment (diagnos- } \\
\text { tic, ethic, therapeutic) }\end{array}$ \\
\hline $\begin{array}{l}\text { University of Massachusetts (Amherst) } \\
\quad \text { (Worcester) (Boston) } \\
\text { www.umass.edu } \\
\text { www.ummed.edu } \\
\text { www.umb.edu }\end{array}$ & $\mathrm{PhD}$ & 1994 & $\begin{array}{l}\text { Clinical research (adolescent health, cardiac } \\
\text { care, diabetes care, empowerment, human } \\
\text { response to health and illness, therapeutic } \\
\text { touch, and violence) }\end{array}$ \\
\hline $\begin{array}{l}\text { University of Massachusetts (Lowell) } \\
\text { www.uml.edu }\end{array}$ & $\mathrm{PhD}$ & 1996 & Health promotion \\
\hline $\begin{array}{l}\text { University of Michigan (Ann Arbor) } \\
\text { www.umich.edu }\end{array}$ & $\mathrm{PhD}$ & 1975 & $\begin{array}{l}\text { Biobehavior; nursing systems/administration; } \\
\text { women's health }\end{array}$ \\
\hline $\begin{array}{l}\text { Wayne State University (Detroit) } \\
\text { www.wayne.edu }\end{array}$ & $\mathrm{PhD}$ & 1975 & $\begin{array}{l}\text { Self-Care \& Care giving; Urban Health; Clinical } \\
\text { Therapeutics; Behavior in Health and IIIness }\end{array}$ \\
\hline $\begin{array}{l}\text { University of Minnesota (Minneapolis) } \\
\text { www.umn.edu }\end{array}$ & $\mathrm{PhD}$ & 1983 & $\begin{array}{l}\text { Health-related behaviors; human responses to } \\
\text { environmental and life process events; phe- } \\
\text { nomenon of health; organization and delivery } \\
\text { of nursing knowledge; organization and } \\
\text { delivery of nursing care }\end{array}$ \\
\hline $\begin{array}{l}\text { University of Mississippi Medical Center (Jack- } \\
\text { son) }\end{array}$ & $\mathrm{PhD}$ & 1997 & $\begin{array}{l}\text { Biological/physiological track; human experi- } \\
\text { ences in health care }\end{array}$ \\
\hline $\begin{array}{l}\text { www.umsmed.edu } \\
\text { Saint Louis University } \\
\text { www.slu.edu }\end{array}$ & $\mathrm{PhD}$ & 1990 & \\
\hline $\begin{array}{l}\text { University of Missouri at Columbia, Kansas } \\
\quad \text { City, St. Louis } \\
\text { www.missouri.edu } \\
\text { www.umkc.edu } \\
\text { www.umsl.edu }\end{array}$ & $\mathrm{PhD}$ & 1994 & $\begin{array}{l}\text { Nursing interventions and nursing outcomes; } \\
\text { primary prevention; health care systems, } \\
\text { health promotion and protection; health res- } \\
\text { toration and support }\end{array}$ \\
\hline $\begin{array}{l}\text { University of Nebraska Medical Center } \\
\quad \text { (Omaha) } \\
\text { www.unmc.edu }\end{array}$ & $\mathrm{PhD}$ & 1989 & \\
\hline $\begin{array}{l}\text { Rutgers, The State University of New Jersey } \\
\text { (Newark) }\end{array}$ & $\mathrm{PhD}$ & 1990 & Health promotion; living with chronic conditions \\
\hline www.rutgers.edu & & & \\
\hline $\begin{array}{l}\text { Adelphi University (Garden City, NY) } \\
\text { www.adlephi.edu }\end{array}$ & $\mathrm{PhD}$ & $\begin{array}{l}1981 \text { (no longer } \\
\text { admitting stu- } \\
\text { dents) }\end{array}$ & $\begin{array}{l}\text { Broad areas of study_primarily qualitative } \\
\text { research }\end{array}$ \\
\hline $\begin{array}{l}\text { Columbia University (New York) } \\
\text { www.columbia.edu }\end{array}$ & DNSc & 1993 & $\begin{array}{l}\text { Clinical nursing research and leadership; } \\
\text { health policy and health services research }\end{array}$ \\
\hline $\begin{array}{l}\text { New York University } \\
\text { www.nyu.edu }\end{array}$ & $\mathrm{PhD}$ & 1934 & $\begin{array}{l}\text { Research, theory, and development in nursing } \\
\text { science }\end{array}$ \\
\hline $\begin{array}{l}\text { SUNY (Buffalo) } \\
\text { www.buffalo.edu }\end{array}$ & DNS & 1987 & Clinical nursing research \\
\hline $\begin{array}{l}\text { Teacher's College, Columbia University (New } \\
\text { York) } \\
\text { www.columbia.edu }\end{array}$ & $\mathrm{EdD}$ & 1933 & $\begin{array}{l}\text { Professorial role (nurse educator); self-care; } \\
\text { rehabilitation; violence; addictions; child/ } \\
\text { adolescent health }\end{array}$ \\
\hline $\begin{array}{l}\text { University of Rochester } \\
\text { www.rochester.edu }\end{array}$ & $\mathrm{PhD}$ & 1978 & \\
\hline $\begin{array}{l}\text { University of North Carolina (Chapel Hill) } \\
\text { www.unc.edu }\end{array}$ & $\mathrm{PhD}$ & 1988 & $\begin{array}{l}\text { Responses to health and illness; prevention } \\
\text { and management of chronic health problems } \\
\text { in vulnerable people }\end{array}$ \\
\hline $\begin{array}{l}\text { Case Western Reserve (Cleveland) } \\
\text { www.cwru.edu }\end{array}$ & $\mathrm{PhD}, \mathrm{ND}$ & 1972 & \\
\hline $\begin{array}{l}\text { Kent State University (Kent, OH) } \\
\text { www.kent.edu }\end{array}$ & $\mathrm{PhD}$ & $\begin{array}{l}\text { Approval, Fall } \\
2000\end{array}$ & $\begin{array}{l}\text { Women's health; chronic illness, stress and } \\
\text { coping; gerontology }\end{array}$ \\
\hline $\begin{array}{l}\text { Ohio State University (Columbus) } \\
\text { www.osu.edu }\end{array}$ & $\mathrm{PhD}$ & 1985 & \\
\hline $\begin{array}{l}\text { University of Cincinnati Medical Center } \\
\text { www.uc.edu }\end{array}$ & $\mathrm{PhD}$ & 1990 & \\
\hline
\end{tabular}


TABLE 6. (Continued)

\begin{tabular}{|c|c|c|c|}
\hline Location of Program and Website & Degrees Offered & Year Established & Areas of Research Focus (Where Available) \\
\hline $\begin{array}{l}\text { Oregon Health Sciences University (Portland) } \\
\text { www.ohsu.edu }\end{array}$ & $\mathrm{PhD}$ & 1985 & $\begin{array}{l}\text { Gerontological nursing; families in health, ill- } \\
\text { ness, and transitions }\end{array}$ \\
\hline $\begin{array}{l}\text { Duquesne University (Pittsburgh) } \\
\text { www.duq.edu }\end{array}$ & $\mathrm{PhD}$ & 1994 & \\
\hline $\begin{array}{l}\text { University of Pennsylvania (Philadelphia) } \\
\text { www.upenn.edu }\end{array}$ & $\mathrm{PhD}$ & 1979 & $\begin{array}{l}\text { Clinical research; health care policy; historical } \\
\text { research }\end{array}$ \\
\hline $\begin{array}{l}\text { University of Pittsburgh } \\
\text { www.pitt.edu }\end{array}$ & $\mathrm{PhD}$ & 1954 & \\
\hline $\begin{array}{l}\text { Widener University (Chester) } \\
\text { www.widener.edu }\end{array}$ & DNSc & 1984 & Educational leadership \\
\hline $\begin{array}{l}\text { University of Rhode Island (Kingston) } \\
\text { www.uri.edu }\end{array}$ & $\mathrm{PhD}$ & 1985 & Client/client-nurse/practice domains \\
\hline $\begin{array}{l}\text { University of South Carolina (Columbia); } \\
\text { Medical University of South Carolina } \\
\text { (Charleston) }\end{array}$ & $\mathrm{PhD}$ & $\begin{array}{l}1986 \text { (added } \\
\text { MUSC in 1994) }\end{array}$ & \\
\hline $\begin{array}{l}\text { www.sc.edu } \\
\text { www.musc.edu }\end{array}$ & & & \\
\hline $\begin{array}{l}\text { University of Tennessee-Knoxville } \\
\text { www.utk.edu }\end{array}$ & $\mathrm{PhD}$ & 1989 & $\begin{array}{l}\text { Management of complex systems; health } \\
\text { policy }\end{array}$ \\
\hline $\begin{array}{l}\text { University of Tennessee-Memphis } \\
\text { www.utmem.edu }\end{array}$ & $\mathrm{PhD}$ DNSc & $1988(\mathrm{PhD})$ & \\
\hline $\begin{array}{l}\text { Vanderbilt University (Nashville) } \\
\text { www.vanderbilt.edu }\end{array}$ & $\mathrm{PhD}$ & 1993 & $\begin{array}{l}\text { Response to health and illness across the life } \\
\text { span }\end{array}$ \\
\hline $\begin{array}{l}\text { Texas Tech University (Lubbock) } \\
\text { www.ttuhsc.edu }\end{array}$ & $\mathrm{PhD}$ & 1991 & Clinical research \\
\hline $\begin{array}{l}\text { Texas Woman's University (Denton, Houston) } \\
\text { www.twu.edu }\end{array}$ & $\mathrm{PhD}$ & 1971 & Women's health \\
\hline $\begin{array}{l}\text { University of Texas at Austin } \\
\text { www.utexas.edu }\end{array}$ & $\mathrm{PhD}$ & 1974 & $\begin{array}{l}\text { Parent-child; adult health; mental health; } \\
\text { nursing systems; community health }\end{array}$ \\
\hline $\begin{array}{l}\text { University of Texas Health Science Center at } \\
\text { Houston }\end{array}$ & DSN & 1996 & \\
\hline www.uth.tmc.edu & & & \\
\hline $\begin{array}{l}\text { University of Texas Health Science Center at } \\
\text { San Antonio }\end{array}$ & $\mathrm{PhD}$ & 1991 & $\begin{array}{l}\text { Clinical nurse scientist; outcomes research and } \\
\text { nursing interventions }\end{array}$ \\
\hline www.uthscsa.edu & & & \\
\hline $\begin{array}{l}\text { University of Texas Medical Branch at } \\
\text { Galveston } \\
\text { www.utmb.edu }\end{array}$ & $\mathrm{PhD}$ & 1997 & Health practices in nursing \\
\hline $\begin{array}{l}\text { University of Utah (Salt Lake City) } \\
\text { www.utah.edu }\end{array}$ & $\mathrm{PhD}$ & 1977 & \\
\hline $\begin{array}{l}\text { George Mason University (Fairfax) } \\
\text { www.gum.edu }\end{array}$ & $\mathrm{PhD}$ & 1986 & $\begin{array}{l}\text { Executive management (education or service); } \\
\text { health policy; health care ethics }\end{array}$ \\
\hline $\begin{array}{l}\text { Virginia Commonwealth University (Richmond) } \\
\text { www.vcu.edu }\end{array}$ & $\mathrm{PhD}$ & 1986 & $\begin{array}{l}\text { Human health and illness; nursing systems; } \\
\text { biology of health and illness }\end{array}$ \\
\hline $\begin{array}{l}\text { University of Virginia (Charlottesville) } \\
\text { www.virginia.edu }\end{array}$ & $\mathrm{PhD}$ & 1982 & \\
\hline $\begin{array}{l}\text { University of Washington (Seattle) } \\
\text { www.u.washington.edu }\end{array}$ & $\mathrm{PhD}$ & 1978 & Human health ecology \\
\hline $\begin{array}{l}\text { University of Wisconsin-Madison } \\
\text { www.wisc.edu }\end{array}$ & $\mathrm{PhD}$ & 1982 & $\begin{array}{l}\text { Individual/family health promotion; illness pre- } \\
\text { vention and management of impaired health; } \\
\text { clinical outcomes }\end{array}$ \\
\hline $\begin{array}{l}\text { University of Wisconsin-Milwaukee } \\
\text { www.uwm.edu }\end{array}$ & $\mathrm{PhD}$ & 1984 & $\begin{array}{l}\text { Specialization within the program is focused on } \\
\text { a particular area of nursing and the context } \\
\text { within which it occurs }\end{array}$ \\
\hline Hampton University & & & $\begin{array}{l}\text { Preparation of nurse scholars and researchers } \\
\text { to advance scientific knowledge and influ- } \\
\text { ence the development of effective health } \\
\text { care policies and practices }\end{array}$ \\
\hline Southern University & & & Delete. Program not approved. \\
\hline
\end{tabular}

Sources: Completed Survey forms; AACN (1998) Institutions Offering Doctoral Programs in Nursing and Degrees Conferred; School/college of nursing website 10/99. 
sity of ( alifornia-San Francisco) dropped their professional degree programs.

The trend toward increasing emphasis on the PhD was supported. In reporting on the impression of doctoral students, Carpenter and Hudacek (1996) stated, "nursing's struggle for credibility among other academics and heal th care professionals seems to direct the path that leads toward the doctoral degree- and that path is clearly toward the PhD in nursing" ( $p$. 45). Later, H udacek and Carpenter (1998) stated that students in all types of doctoral programs believed their curriculum prepared them to conduct research. Additionally, students perceived the $\mathrm{PhD}$ as preparing the student for a research career whereas the $E d D$ and DNS students perceived their role preparation as educators and clinicians. Finally, the lack of course offerings with an educational focus in most programs is clearly worth noting, given that the majority of doctorally prepared faculty assume teaching positions.

The purpose of the cognate within doctoral programs needs to be reviewed because these courses often serve as the only substantive content area. The lack of nursing content in some programs is conspicuous and has been previously addressed by Meleis (1988, 1992), C hristman (1998), and Ketefian (1993). $\mathrm{H}$ istorically, the specialized content has been offered at the master's level, but the knowledge base in nursing science and research has grown exponentially in the past decade. This content should be included as part of doctoral study rather than relying on knowledge transferred from other disciplines into nursing. D octoral curriculum committees should examine the role of cognates and redefine their inclusion after a systematic review of nursing science.

\section{Summary and Conclusions}

Possible reasons for the similarity of nursing doctoral programs include the foundational faculty connections to many of the earliest programs (e.g., N YU; Teacher's College, Columbia; University of Pittsburgh; University of California-San Francisco; Texas Woman's U niversity). This logic supports the earlier work of Snyder-Halpern (1986) who found more similarities than differences among the various doctoral programs in nursing. Additionally, students also perceive little difference in personal and professional growth, available support systems, or role preparation within the 3 types of programs. H owever, the PhD is alleged among students to place more emphasis on conducting research (H udacek \& Carpenter, 1998).

There appears to be an increasing movement away from the D N S, DSN , D N Sc and programs that may warrant renewed examination from a national perspective. The multiple avenues for entry into practice (e.g., $B S N, A D N$, diploma) have resulted in confusion toward professional nursing, and the similarity in programs between the PhD and the clinical degree may exacerbate an already confused public.

There is a cogent argument to place less emphasis on process courses (i.e., theory construction, research methods, statistics) and more emphasis on nursing issues and nursing science. Given the current emphasis at baccalaureate degree programs in hiring doctorally prepared faculty to teach, perhaps there should be more options to incorporate nursing education concepts into the program of study. Because so many of these schools expect faculty to emphasize quality teaching over grant writing and research, including curriculum and instruction, educational theories, and role of the faculty would meet the needs of many students. In this study, only Emory University reported required content in nursing education.

D octoral education in nursing has grown dramatically in the past 2 decades and this growth has had a vital impact on the educational and research processes. Given the continued demand for doctorally prepared faculty, clinicians, and administrators, these programs should continue to ensure an infrastructure that will promote the health and well being of the public. Doctoral education programs are now available in most states and the findings of this study suggest curriculum content is very similar across programs. Prospective doctoral students would be wise to search for a faculty mentor or for a program that specializes in their area of research interest because there are so few differences in course offerings among doctoral programs.

\section{References}

American Association of Colleges of Nursing. (1998). Institutions offering doctoral programs in nursing and degrees conferred. Washington, D C: AACN .
American Association of Colleges of Nursing. (1993). Indicators of Quality in Doctoral Programs in Nursing. Washington, DC: AACN . 
Blancett, S. S. (1989). Defining doctoral education. N urse Educator, 14, 3.

Carpenter, D. R., \& H udacek, S. (1996). On doctoral education in nursing: The voice of the student (Publication N o. 14-6703). N ew York: N LN Press.

Christman, L. (1998). W ho is a nurse? Image Journal of Nursing Scholarship, 30, 211-214.

D owns, F. S. (1989). Differences between the professional doctorate and the academic/research doctorate. Journal of Professional Nursing, 5, 261-265.

Gosnell, D. J., \& Biordi, D. L. (1999). Personnel resource distribution for nursing programs in Carnegieclassified Research I and II and Doctoral I institutions. Journal of Professional N ursing, 15, 44-51.

Grace, H. K. (1989). Issues in doctoral education in nursing. Journal of Professional N ursing, 5, 266-270.

Higher Education Directory-1998. Falls Church, VA: Higher Education Publications, Inc.

H odges, L. C., Satkowski, T. C., \& Ganchorre, C. (1998). Career opportunities for doctoral-prepared nurses. M edSurg N ursing, 7, 114-120.

H udacek, S., \& Carpenter, D. R. (1998). Student perceptions of nurse doctorates: Similarities and differences. Journal of Professional N ursing, 14, 14-21.

Jones, K. D., \& Lutz, K. F. (1999). Selecting doctoral programs in nursing: Resources for students and faculty. Journal of Professional N ursing, 15, 245-252.

Ketefian, S. (1993). Essentials of doctoral education:
O rganization of program around knowledge areas. Journal of Professional N ursing, 9, 255-261.

M eleis, A. I. (1992). On the way to scholarship: From master's to doctorate. Journal of Professional Nursing, 8, 328-334.

M eleis, A. I. (1988). D octoral education in nursing: Its present and its future. Journal of Professional Nursing, 4, 436-446.

Rickelman, B. L., \& Brown, B. J. (1989). The race for resources: Who can, who does, and who should obtain them? In S. E. H art (Ed.), Doctoral education in nursing: $\mathrm{H}$ istory, process and outcome (Publication No. 15-2238). $\mathrm{N}$ ew York: N LN .

Snyder-H al pern, R. (1986). D octoral programs in nursing: An examination of curriculum similarities and differences. Journal of N ursing Education, 25, 358-365.

Starck, P. L., Duffy, M. E., \& Vogler, R. (1993). D eveloping a nursing doctorate for the21st century. Journal of Professional N ursing, 9, 212-219.

Ziemer, M. M ., Fitzpatrick, M . L., Valiga, T., M anfredi, C., \& Brown, J. (1991). Curricula of doctoral programs in nursing. In M. G arbin (Ed.), Assessing educational outcomes: Third national conference on measurement and evaluation in nursing (Publication N 0. 15-2447). N ew York: N LN .

Ziemer, M. M ., Brown, J., Fitzpatrick, M . L., M anfredi, C., O'Leary, J., \& Valiga, M. M. (1992). Doctoral programs in nursing: Philosophy, curricula, and program requirements. Journal of Professional N ursing, 8, 56-62. 